\title{
PENGARUH RETURN ON ASSETS DAN CURRENT RATIOTERHADAP KEBIJAKAN DEVIDEN PADA PERUSAHAAN SEKTOR ANEKA INDUSTRI DI BURSA EFEK INDONESIA
}

\author{
Novi Fadhila, Nora \\ Program Studi Akuntansi, Fakultas Ekonomi dan Bisnis UMSU \\ novifadhila@umsu.ac.id, norasipayung1197@gmail.com
}

\begin{abstract}
Return On Asset is a return from the management of investment and company assets, which is one of the indicators of profitability for the company with adequate measurement of the effectiveness of the entire company. Meanwhile, the current ratio is a reflection of the company's ability to pay off its current debt by looking at the condition of the company's current assets. The purpose of this study is to examine and analyze the effect of Return On Asset and Current Ratio on dividend policy in various industrial securities sector companies on the Indonesia Stock Exchange, either simultaneously or partially. The method used is quantitative associative, with purposive sampling technique, documentation technique and data analysis technique used is multiple linear regression. With the research results simultaneously, return on assets and current ratio do not affect dividend policy. Partially, return on assets has no effect on dividend policy, as well as current ratio to dividend policy.
\end{abstract}

\section{Keyword : Return On Assets, Current Ratio, Dividen policy}

\section{Pendahuluan}

Pertumbuhan ekonomi yang pesat mengakibatkan persaingan yang ketat, sehingga para pelaku usaha berupaya menampilkan dirinya menjadi yang terbaik. Go public merupakan salah satu cara perusahaan menampilkan dirinya kepada masyarakat dalam upaya meningkatkan nilai perusahaan. Kegiatan yang dilakukan untuk go public adalah dengan melakukan penawaran saham atau efek lainnnya berdasarkan tata cata yang diatur oleh Undang-Undang Pasar Modal dan Peraturan Pelaksanaannya.

Pihak manajemen perusahaan harus dapat mengelola kondisi internal perusahaan agar dapat stabil, sehingga pihak eskternal memiliki kepercayaan terhadap manajemen perusahaan dalam persaingan serta bertahan dalam mengelola usaha. Selain perusahaan harus selalu menyesuaikan kondisi perkembangan usaha untuk dapat beradaptasi dengan perubahan pasar, namun juga harus dapat mempertahankan kelangsungan hidup perusahaan tersebut (Prihanthini \& Sari, 2013).

Tingkat perkembangan pasar modal dan industri-industri sekuritas pada suatu negara merupakan tolak ukur untuk melihat perkembangan ekonomi negara tersebut. Sementara itu, perusahaan yang ingin dapat bersaing serta bertahan dalam suatu industri harus memperhatikan kegiatan investasinya. Sehingga, perusahaan perlu meyakinkan dan menarik investor untuk berinvestasi dan membeli saham dari perusahaan tersebut. Bagi para penanam modal untuk melakukan keputusan investasi merupakan kebijakan yang strategis, akan tetapi para investor sering dihadapkan berbagai macam resiko dan ketidakpastian yang sulit untuk diprediksi, salah satunya adalah pembayaran dividen (Utami \& Robin, 2015).

Dividen dibagikan apabila perusahaan memperoleh keuntungan. Pada umumnya perusahaan sebisa mungkin mempertahankan peningkatan deviden dari tahun ke tahun. Dividen yang stabil dapat memberikan kesan kepada investor bahwa perusahaan mempunyai prospek yang baik dimasa yang akan datang, sehingga kepercayaan investor terhadap perusahaan makin besar (Hikmah, 2011). Untuk itu perusahaan memerlukan adanya kebijakan 
dividen guna memutuskan apakah dividen akan dibagikan ataupun ditahan yang berkaitan dengan dividen pay out ratio yaitu besarnya dividen yang dibagikan pada pemegang saham. Apabila perusahaan memilih untuk membagikan laba sebagai dividen, maka akan mengurangi laba yang ditahan dan selanjutnya mengurangi total sumber dana intern atau internal financing (Sartono, 2015).

"Dividend Payout Ratio merupakan rasio yang menunjukan hasil perbandingan antara dividen tunai perlembar saham dengan laba perlembar saham. Rasio ini menggambarkan jumlah laba dari setiap lembar saham yang dialokasikan dalam bentuk dividen" (Hery, 2016). Dalam menentukan pembagian deviden, perusahaan perlu memperhatikan berbagai faktor yang mempengaruhi kebijakan deviden itu sendiri, menururt (Zais, 2017) terdapat banyak faktor yang mempengaruhi kebijakan dividen dalam suatu perusahaan adalah nilai saham, profitabilitas, struktur modal dan likuiditas.

Salah satu alat untuk mengukur kekuatan perusahaan dalam menghasilkan keuntungan (profit) adalah Return On Assets. Secara umum Return On Assets adalah salah satu alat ukur profitabilitas untuk mengetahui kemampuan perusahaan dalam mengelola asetnya untuk menghasilkan laba selama suatu periode (Jufrizen, Sari, Radiman, Muslih, \& Putri, 2019).

Likuiditas merupakan kemampuan perusahaan untuk melunasi kewajiban jangka pendeknya. Banyak perusahaan memiliki potensi jangka panjang yang luar biasa, namun hancur akibat masalah likuiditas jangka pendek (Stice, 2015). Rasio yang digunakan untuk mengukur kemampuan perusahaan dalam memenuhi kewajiban jangka pendeknya adalah Current Ratio (CR), (Jufrizen \& Sari, 2019). Rasio lancar adalah rasio keuangan yang mengukur apakah perusahaan memiliki sumber daya yang cukup untuk membayar utangutangnya selama 12 bulan ke depan. Ini membandingkan aset perusahaan saat ini untuk kewajiban lancarnya, (Wahyuni, 2017)

Apabila rasio lancar tersebut rendah, dapat dikatakan bahwa perusahaan kurang modal untuk membayar utang. Namun apabila hasil pengukuran rasio tinggi, belum tentu kondisi perusahaan sedang baik, hal ini dapat saja terjadi karena kas tidak digunakan sebaik mungkin. Bila perusahaan dapat memenuhi semua kewajibannya maka perusahaan dalam keadaan likuid. Kondisi keuangan yang baik akan berpengaruh kepada profit yang didapat perusahaan akan tinggi. Likuiditas yang tinggi tanpa adanya pemanfaatan nilai yang dimiliki untuk menghasilkan laba bagi perusahaan akan menjaadi beban karena bisa dikatakan kas tersebut menganggur (idle fund), banyaknya piutang yang tidak tertagih dan rendahnya pinjaman jangka pendek. Hasil yang berbeda akan muncul jika perusahaan merencanakan likuiditas yang tinggi sebagai modal kerja dalam jangka antisipasi terhadap pembayaran hutang jangka pendek maupun bagian dari hutang jangka panjang yang harus segera dibayarkan, (Muslih, 2019). Berikut data penelitian yang digunakan pada penelitian ini:

Tabel 1.1

Data Kebijakan Deviden Pada Perusahaan sub Sektor Aneka Industri di Bursa Efek Indonsia Periode 2015-2019

\begin{tabular}{|l|r|r|r|r|r|}
\hline \multirow{2}{*}{ Kode Perusahaan } & \multicolumn{5}{|c|}{ Tahun } \\
\cline { 2 - 6 } & $\mathbf{2 0 1 5}$ & $\mathbf{2 0 1 6}$ & $\mathbf{2 0 1 7}$ & \multicolumn{1}{c|}{$\mathbf{2 0 1 8}$} & \multicolumn{1}{c|}{$\mathbf{2 0 1 9}$} \\
\hline ICBP & 0,01 & 0,01 & 0,01 & 0,01 & 0,01 \\
\hline ROTI & 0,10 & 0,19 & 0,51 & 0,42 & 0,29 \\
\hline SKLT & 0,17 & 0,20 & 0,14 & 0,14 & 0,12 \\
\hline HMSP & 1,18 & 0,81 & 0,99 & 0,92 & 0,99 \\
\hline KLBF & 0,04 & 0,38 & 0,42 & 0,47 & 0,48 \\
\hline UNVR & 0,99 & 0,15 & 0,16 & 0,17 & 0,21 \\
\hline MLBI & 0,59 & 0,94 & 0,81 & 0,92 & 1,02 \\
\hline MYOR & 0,11 & 0,19 & 0,29 & 0,34 & 0,34 \\
\hline
\end{tabular}

Sumber: Data diolah (2020) 
Berdasarkan tabel 1.1 dapat dilihat bahwa rata-rata kebijkana deviden pada perusahaan sub industri konusmsi yang terdaftar di Bursa Efek Indonesia mengalami peningkatan hal ini diduga karena adanya peningkatan deviden dan diikuti meningkatnya jumlah saham yang beredar. Menurut (Siswantini, 2014) Kebijakan dividen adalah keputusan apakah laba yang diperoleh dari perusahaan dibagikan ke pemegang saham sebagai dividen atau laba ditahan untuk pembiayaan investasi perusahaan di masa mendatang. Menurut (Siswantini, 2014) Kebijakan dividen adalah keputusan apakah laba yang diperoleh dari perusahaan dibagikan ke pemegang saham sebagai dividen atau laba ditahan untuk pembiayaan investasi perusahaan di masa mendatang. Sedangkan menurut (Wahyuni \& Hafiz, 2018) Dividend Payout Ratio adalah perbandingan antara dividen yang dibayarkan dengan laba bersih yang didapatkan, semakin tinggi Dividend Payout Ratio akan menguntungkan pihak investor tetapi pada pihak perusahaan akan memperlemah internal financial karena memperkecil laba ditahan. Tetapi sebaliknya Dividend Payout Ratio semakin kecil akan merugikan pemegang saham (investor) internal financial perusahaan semakin kuat.

Kenaikan dividen dalam jumlah kecil atau penurunan dividen yang dibayarkan oleh perusahaan memberikan sinyal yang buruk bagi pemegang saham dan mengindikasikan bahwa perusahaan mengalami penurunan profit atau kerugian yang tentu akan menurunkan nilai perusahaan. Perusahaan yang memiliki nilai perusahaan tinggi memberikan sinyal positif bahwa sudah kompeten dalam manajemen dan menjalankan kegiatan operasionalnya, hal ini akan membuat investor tertarik untuk menanamkan modalnya berupa saham (Wati, 2018).

\section{Tabel 1.2}

Data Return On Assets Pada Perusahaan sub Sektor Aneka Industri di Bursa Efek Indonsia Periode 2015-2019

\begin{tabular}{|c|c|c|c|c|c|}
\hline \multirow{2}{*}{$\begin{array}{c}\text { Kode } \\
\text { Perusahaan }\end{array}$} & \multicolumn{5}{|c|}{ Tahun } \\
\hline & 2015 & 2016 & 2017 & 2018 & 2019 \\
\hline ICBP & 11,00 & 12,56 & 11,20 & 13,56 & 140,70 \\
\hline ROTI & 9,99 & 9,58 & 2,97 & 2,89 & 5,05 \\
\hline SKLT & 5,32 & 3,63 & 3,61 & 4,28 & 5,68 \\
\hline HMSP & 27,26 & 30,02 & 29,37 & 29,05 & 26,96 \\
\hline KLBF & 15,02 & 15,43 & 14,76 & 13,76 & 12,52 \\
\hline UNVR & 37,20 & 239,18 & 217,93 & 205,64 & 207,86 \\
\hline MLBI & 23,65 & 43,17 & 53,07 & 42,38 & 42,02 \\
\hline MYOR & 11,02 & 10,75 & 10,93 & 10,00 & 10,71 \\
\hline
\end{tabular}

Sumber: Data diolah (2020)

Berdasarkan tabel 1.2 dapat dilihat bahwa rata rata Return On Assets pada perusahaan sub industri konusmsi yang terdaftar di Bursa Efek Indonesia mengalami peningkatan hal ini diduga karena adanya peningkatan laba bersih dan diikuti oleh peningkatan total aset. Menurut (Wahyuni \& Hafiz, 2018) Return On Asset (ROA) juga merupakan tingkat pengembalian investasi atas investasi perusahaan pada aktiva tetap yang digunakan untuk operasional. Return On Asset (ROA) yang semakin besar menunjukkan kinerja keuangan semakin baik, karena tingkat pengembalian investasi semakin besar., sehingga dapat dikatakan bahwa Return On Asset (ROA) memiliki pengaruh positif terhadap Dividend Payout Ratio. Semakin tinggi hasil pengembalian atas aset berarti semakin tinggi pula jumlah laba bersih yang dihasilkan oleh setiap rupiah dana yang tertanam dalam total aset. Sebaliknya, semakin rendah hasil pengembalian atas aset berarti semakin rendah pula jumlah laba bersih yang dihasilkan dari setiap rupiah dana yang tertanam dalam total aset, (Hery, 2016).

Tabel 1.3

Data Current Ratio Pada Perusahaan sub Sektor Aneka Industri di Bursa Efek Indonsia Periode 2015-2019

\begin{tabular}{|c|c|c|c|c|c|}
\hline \multirow{2}{*}{ Kode Perusahaan } & \multicolumn{5}{|c|}{ Tahun } \\
\cline { 2 - 6 } & 2015 & 2016 & 2017 & 2018 & 2019 \\
\hline
\end{tabular}




\begin{tabular}{|l|r|r|r|r|r|} 
ICBP & 297,26 & 250,82 & 276,21 & 195,17 & 253,56 \\
\hline ROTI & 205,34 & 296,22 & 225,85 & 357,12 & 169,33 \\
\hline SKLT & 119,24 & 131,53 & 126,30 & 122,44 & 129,00 \\
\hline HMSP & 837,48 & 661,24 & 665,45 & 430,19 & 327,60 \\
\hline KLBF & 369,77 & 413,11 & 450,94 & 465,77 & 438,87 \\
\hline UNVR & 65,39 & 60,56 & 63,36 & 73,24 & 65,28 \\
\hline MLBI & 58,42 & 20,71 & 74,51 & 77,83 & 73,19 \\
\hline MYOR & 236,53 & 225,01 & 237,99 & 265,45 & 342,85 \\
\hline
\end{tabular}

\section{Sumber: Data Diolah (2020)}

Berdasarkan tabel 1.3 dapat dilihat bahwa rata rata Current Ratio pada perusahaan sub sector aneka industri yang terdaftar di Bursa Efek Indonesia mengalami peningkatan hal ini diduga karena adanya peningkatan aset lancar dan ikuti oleh peningkatan total utang lancar.

\section{Kajian Teori}

\subsection{Kebijakan Deviden}

Kebijakan dividen menurut (Martono \& Harjito, 2015) adalah keputusan apakah laba yang diperoleh perusahaan pada akhir tahun akan dibagi kepada pemegang saham dalam bentuk dividen atau akan ditahan untuk menambah modal guna pembiayaan investasi di masa yang akan datang. Selanjutnya menurut (Brigham \& Houston, 2015) kebijakan dividen adalah keputusan Kebijakan dividen didefinisikan keputusan mengenai berapa banyak laba saat ini yang akan dibayarkan sebagai dividen sebagai ganti dari dipertahankan untuk diinvestasikan kembali di dalam perusahaan.

Menurut (Sartono, 2015) ada beberapa hal yang mempengaruhi kebijakan dividen dalam sebuah perusahaan. Adapun faktor-faktor tersebut antara lain adalah sebagai berikut: a. Kebutuhan dana perusahaan

Kebutuhan dana bagi perusahaan dalam kenyataannya merupakan faktor yang harus dipertimbangkan dalam menentukan kebijakan dividen yang akan diambil. Aliran kas perusahaan yang diharapkan, pengeluaran modal di masa datang yang diharapkan, kebutuhan tambahan piutang dan persediaan, pola pengeluaran utang dan masih banyak faktor lain yang mempengaruhi posisi kas perusahaan yang harus dipertimbangkan dalam analisis kebijakan dividen.

b. Likuiditas

Likuiditas perusahaan merupakan pertimbangan utama dalam banyak kebijakan dividen. Karena dividen bagi perusahaan merupakan kas keluar, maka semakin besar posisi kas dan likuiditas perusahaan secara keseluruhan akan semakin besar kemampuan perusahaan untuk membayar dividen.

c. Kemampuan Meminjam

Kemampuan meminjam dalam jangka pendek tersebut akan meningkatan fleksibilitas likuiditas perusahaan. Selain itu, fleksibilitas perusahaan juga dipengaruhi oleh kemampuan perusahaan untuk bergerak di pasar modal dengan mengeluarkan obligasi. Perusahaan yang semakin besar dan sudah establish akan memiliki akses yang lebih baik dipasar modal. Kemampuan meminjam yang lebih besar, fleksibilitas lebih besar akan memperbesar kemampuan membayar dividen.

d. Keadaan Pemegang Saham

Jika perusahaan itu kepemilikan sahamnya relative tertutup, manajemen biasanya mengetahui dividen yang diharapkan pemegang saham dan bertindak dengan tepat. Jika hampir semua pemegang saham berada dalam golongan high tax dan lebih suka menerima capital gain, maka perusahaan dapat mempertahankan dividend payout ratio yang rendah. Dengan dividend payout ratio yang rendah tentunya dapat diperkirakan apakah perusahaan akan menahan laba untuk kesempatan investasi yang profitable. Untuk perusahaan yang 
jumlah pemegang sahamnya besar hanya dapat menilai dividen yang diharapkan pemegang saham dalam konteks pasar.

e. Stabilitas Dividen

Bagi para investor faktor stabilitas dividen akan lebih menarik dari pada dividend payout ratio yang tinggi. Stabilitas disini dalam arti tetap mempertahankan tingkat pertumbuhan perusahaan, yang ditunjukaan oleh koefisien arah yang positif. Saham yang memberikan dividen yang stabil selama periode tertentu akan mempunyai harga yang lebih tinggi dari pada saham yang membayar dividennya dalam prosentase yang tetap terhadap laba. Bagi para investor, pembayaran dividen yang stabil merupakan indikator prospek perusahaan yang stabil pula. Dengan demikian, resiko perusahaan juga relative rendah dibandingkan dengan perusahaan yang membayar dividen tidak stabil.

Mengukur dividen yang dibayarakan oleh perusahan dapat diukur menggunakan salah satu dari ukuran umum dikenal. Menurut (Gumanti, 2015) ukuran kebijakan dividen sebagai berikut:

Dividend yield, yang mengaitkan besaran dividen dengan harga saham perusahaan, secara matematis dapat dinyatakan dengan rumus berikut:

$$
\text { Dividend yield }=\frac{\text { Deviden } \text { Tahunan } \text { Per Saham }}{\text { Harga Perlembar Saham }}
$$

Dividend payout, rasio pembayaran dividen diukur dengan cara membagi besarnya dividen per lembar saham dengan laba bersih per lembar saham, yang secara matematis dapat dinyatakan dengan rumus berikut:

$$
\text { Dividend Payout Ratio }=\frac{\text { Deviden Tunai Per Saham }}{\text { Laba Bersih Perlembar Saham }}
$$

pengukuran yang digunakan adalah Dividen Pay Out Ratio, karena rasio ini memberikan gambaran yang lebih baik terhadap keuntungan yang diperoleh pemegang saham dibandingkan dengan keuntungan yang diperoleh perusahaan. Semakin tinggi rasio akan semakin menguntungkan bagi pemegang saham karena semakin besar tingkat kembalian atas saham yang dimiliki.

\subsubsection{Dividend Payout Ratio (DPR)}

Dividend Payout Ratio (DPR) merupakan persentase pendapatan yang akan dibayarkan kepada pemegang saham dan yang akan dibayarkan sebagai dividen kas. Menurut (Hery, 2016) "Dividend Payout Ratio (DPR) merupakan rasio yang menunjukan hasil perbandingan antara dividen tunai perlembar saham dengan laba perlembar saham. Rasio ini menggambarkan jumlah laba dari setiap lembar saham yang dialokasikan dalam bentuk dividen". Dengan begitu rasio ini digunakan sebagai salah satu proksi (pendekatan) dalam menetapkan kebijakan dividen yaitu saat mengambil keputusan.

Ada banyak faktor yang mempengaruhi kebijakan dividen yang diterapkan oleh perusahaan. Menurut (Horne \& Wachowicz, 2015) faktor yang mempengaruhi kebijakan dividen suatu perusahaan antara lain:

1. Kandungan Informasi.

Ketika laba jatuh dan perusahaan tidak memotong dividennya, pasar mungkin akan lebih yakin pada saham perusahaan dari pada jika dividen tiba-tiba dikurangi.

2. Keinginan untuk mendapatkan penghasilan.

Pada investor yang menginginkan penghasilan periodik tertentu lebih menyukai perusahaan yang dimiliki dividen stabil, walaupun kedua perusahaan tersebut mungkin memiliki pola laba dan pembayaran dividen jangka panjang yang sama.

3. Pertimbangan Institusional. 
Dividen yang stabil mungkin menguntungkan dari sisi hukum untuk memungkinkan para investor institusi tertentu membeli saham biasa.

Dividend Payout Ratio (DPR) merupakan persentase pendapatan yang akan dibayarkan kepada pemegang saham yang akan dibayarkan sebagai dividen kas. Persentase dari pendapatan yang akan dibayarkan kepada pemegang saham dengan perbandingan antara Dividen Per Share (DPS) dan Earning Per Share (EPS).

Menurut (Wahyuni \& Hafiz, 2018) untuk menentukan Dividend Payout Ratio (DPR) dapat digunakan rumus:

$$
D P R=\frac{D P S}{E P S}
$$

\subsection{Return On Asset}

Return On Asset mampu mengukur kemampuan perusahaan manghasilkan keuntungan pada masa lampau untuk kemudian diproyeksikan di masa yang akan datang. "ROA menunjukkan kemampuan perusahaan dengan menggunakan seluruh aktiva yang dimiliki untuk menghasilkan laba setelah pajak".

Sedangkan menurut (Brigham \& Houston, 2015) "rasio laba bersih terhadap total asset mengukur pengembalian atas total asset (ROA) setelah bunga dan pajak." Semakin besar Return On assets (ROA), berarti semakin efisien penggunaan aktiva perusahaan atau dengan kata lain dengan jumlah aktiva yang sama bisa dihasilkan laba yang lebih besar, dan sebaliknya.

Return On Asset mempunyai tujuan dan manfaat bukan hanya bagi manajemen dan pemilik perusahaan saja, tetapi juga bagi pihak luar yang memiliki hubungan atau kepentingan seperti: investor dan pemegang saham. tujuan perusahaan menggunakan rasio Rerurn On Assets (ROA) adalah :

1. Untuk mengukur atau menghitung laba yang diperoleh perusahaan dalam suatu periode tertentu.

2. Untuk menilai posisi laba perusahaan tahun sebelumnya dengan tahun sekarang.

3. Untuk menilai perkembangan laba dari waktu ke waktu.

4. Untuk menilai besarnya laba bersih sesudah pajak dengan modal sendiri.

5. Untuk mengukur produktivitas seluruh dana perusahaan yang digunakan baik modal pinjaman maupun modal sendiri.

6. Untuk mengukur produktivitas dari seluruh dana perusahaan yang digunakan baik modal pinjaman maupun modal sendiri.

Adapun manfaat Return On Asset bagi perusahaan:

1. Mengetahui besarnya tingkat laba perusahaan yang diperoleh perusahaan dalam suatu periode tertentu.

2. Mengetahui posisi laba perusahaan tahun sebelumnya dengan tahun sekarang.

3. Mengetahui perkembangan laba dari waktu ke waktu.

4. Mengetahui besarnya laba bersih sesudah pajak dengan modal sendiri.

5. Mengetahui produktifitas seluruh dana perusahaan yang digunakan baik modal pinjaman maupun modal sendiri (Kasmir, 2017).

Return On Asset merupakan salah satu rasio profitabilitas yang paling sering dilihat karena dapat menunjukkan kemampuan perusahaan dalam menghasilkan laba. Adapun faktor-faktor yang mempengaruhi tinggi rendahnya Return On Asset: (1) Profit Margin yaitu perbandingan antara net operating income dengan net sales. (2) Tingkat Perputaran Aktiva usaha yaitu kecepatan berputarnya operating assets dalam suatu periode tertentu (Riyanto, 2017). Besarnya Return On Asset dapat dihitung menggunakan rumus:

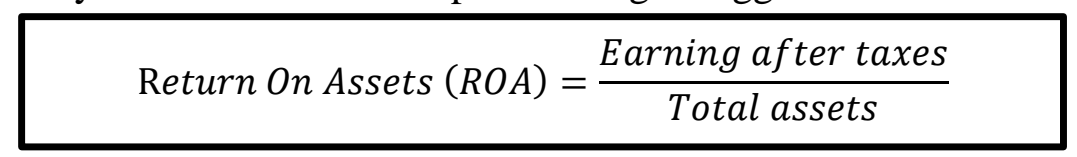

(Sudana, 2015) 


\subsection{Current Ratio}

Merupakan rasio yang menunjukkan kemampuan perusahaan dalam melunasi kewajiban lancarnya dengan aktiva lancarnya. current ratio merupakan perbandingan antara aktiva lancar dengan hutang lancar. Rasio ini menunjukkan bahwa nilai kekayaan lancar (yang segera dapat dijadikan uang) ada sekian kalinya hutang jangka pendek. Current ratio ini juga menunjukkan tingkat keamanan kreditor jangka pendek atau kemampuan perusahaan untuk membayar hutang-hutang tersebut, tetapi Current ratio yang tinggi belum tentu menjamin akan dibayarnya hutang perusahaan yang sudah jatuh tempo karena proporsi atau distribusi dari aktiva lancar yang tidak menguntungkan (Munawir, 2015).

Adapun tujuan dan manfaat current ratio adalah sebagai berikut :

1. Untuk mengukur kemampuan perusahaan membayar kewajiban atau utang yang segera jatuh tempo pada saat ditagih.

2. Unuk mengukur kemampuan perusahaan membayar kewajiban jangka pendek dengan kativa lancar secara keseluruhan.

3. Untuk mengukur kemampuan perusahaan membayar kewajiban jangka pendek dengan aktiva lancar tanpa memperhitungkan persediaan dan piutang.

4. Sebagai alat perencanaan ke depan, terutama yang berkaitan dengan perencanaan kas dan piutang.

5. Untuk melihat posisi dan kondisi likuiditas perusahaan dari waktu ke waktu dengan membandingkan untuk beberapa periode.

6. Menjadi alat pemicu bagi pihak manajemen untuk memperbaiki kinerja perusahaan pada saat ini (Kasmir, 2017).

Perusahaan yang mengalami kesulitan keuangan akan membayar hutangnya secara lambat.

Jika hutang lancar bertambah lebih cepat dari aktiva lancar maka rasio lancar akan turun, ini menandakan adanya masalah.

Adapun faktor-faktor yang mempengaruhi current ratio adalah sebagai berikut :

1. Distribusi dari pos-pos aktiva lancar.

2. Data tren dari aktiva lancar dan hutang jangka pendek untuk jangka waktu 5 atau 10 tahun.

3. Syarat kredit yang diberikan oleh kreditur kepada perusahaan dalam pengembalian barang, dan syarat kredit yang diberikan perusahaan kepada langganan dalam penjualan barang.

4. Nilai sekarang atau nilai pasar atau nilai ganti dari barang dagangan dan tingkat pengumpulan piutang.

5. Kemungkinan adanya perubahan nilai aktiva lancar.

6. Perubahan persediaan dalam hubungannya dengan volume penjualan sekarang dan yang akan datang.

7. Besar kecilnya kebutuhan modal kerja untuk tahun mendatang.

8. Besar kecilnya jumlah kas dan surat-surat berharga dalam hubungannya dengan kebutuhan modal kerja.

9. Credit rating perusahaan pada umumnya.

10. Besar kecilnya piutang dalam hubungannya dengan volume penjualan (Jumingan, 2017).

Current Ratio dapat dihitung menggunakan rumus:

$$
\text { Current Ratio }=\frac{\text { Current Assets }}{\text { Current Liabilitas }} \times 100 \%
$$

(Munawir, 2015). 


\section{Metode Penelitian}

Penelitian ini menggunakan pendekatan assosiatif dan kuantitatif. "pendekatan assosiatif adalah pendekatan yang dilakukan untuk mengetahui hubungan atau pengaruh antara dua variabel atau lebih" (Juliandi, dkk, 2015). Sementara metode kuantitatif dapat diartikan metode penelitian yang berlandaskan pada filsafat positif, digunakan untuk meneliti populasi atau sampel tertentu, pengumpulan data melalui instrumen penelitian, analisis data bersifat kuantitatif/ statistik dengan tujuan untuk menguji hipotesis yang telah ditetapkan (Sugiyono, 2018).

Data yang digunakan merupakan data sekunder yang diambil dari Bursa Efek Indonesia, berupa laporan keuangan perusahaan sector aneka industri yang diakses pada $\underline{w} \boldsymbol{w} \boldsymbol{w} . \boldsymbol{i d x} . \boldsymbol{c o . i d}$. Dari 53 perusahaan yang terdaftar, diambil 8 perusahaan yang dijadikan sampel menggunakan teknik purposive sampling yaitu teknik pengambilan sampel dengan pertimbangan tertentu dengan tujuan agar diperoleh sampel yang sesuai dengan kriteria yang ditentukan (Sugiyono, 2018), dengan kriteria: (1) Perusahaan sektor industri barang konsumsi yang terdaftar di Bursa Efek Indonesia (BEI) Priode 2015-2019. (2) Perusahaan menerbitkan atau mempublikasikan laporan tahunan (Annual Report) perusahaan selama periode pengamatan selama 2015-2019. (3) Perusahaan tersebut memiliki data yang lengkap sesuai kebutuhan peneliti.

Pengumpulan data yang digunakan dalam penelitian ini adalah dengan menggunakan studi dokumentasi, dengan teknik analisis data menggunakan regresi linier berganda.

\section{Hasil Dan Pembahasan}

\subsection{Hasil Penelitian}

Sebelum melakukan analisis regresi berganda terlebih dahulu dilakukan uji lolos kendala liner atau uji asumsi klasik. Tujuan dilakukannya uji asumsi klasik adalah untuk mengetahui apakah suatu variabel normal atau tidak.

Tabel 4.1

Descriptive Statistics

\begin{tabular}{|l|r|r|r|}
\hline & \multicolumn{1}{|c|}{ Mean } & \multicolumn{1}{|c|}{ Std. Deviation } & \multicolumn{1}{|c|}{ N } \\
\hline DPR &, 4060 &, 35678 & 40 \\
\hline ROA & 40,5420 & 64,25776 & 40 \\
\hline CR & 253,9032 & 186,41187 & 40 \\
\hline
\end{tabular}

Pada tabel Descriptive Statistics terlihat bahwa jumlah data penelitian adalah 40, yaitu periode pelaporan 2015 - 2019. Variabel dependen adalah Dividen Pay Out Ratio merupakan rasio pembagian dividen kepada investor dan pemegang saham perusahaan, mempunyai nilai mean sebesar ,4060 menunjukkan bahwa selama 5 tahun pelaporan perusahaan yang menjadi sampel penelitian mempunyai rata-rata dividen payout ratio sebanyak $40 \%$.

Sementara Return On Asset mempunyai nilai 40,5420 yang artinya kemampuan perusahaan dalam menghasilkan laba melalui pengelolaan aktivanya mencapai $4.054 \%$. Artinya perusahaan sudah sangat baik dalam mengelola hartanya untuk menghasilkan laba.

Untuk Current Ratio yang merupakan kemampuan perusahaan melunasi kewajiban lancarnya menggunakan aktiva lancarnya dengan nilai 253,9032, atau $25.390 \%$. Artinya perusahaan akan sangat mampu dalam melakukan pelunasan kewajiban jangka pendeknya dengan menggunakan aktiva lancarnya.

Table 4.2

\section{One-Sample Kolmogorov-Smirnov Test}

\begin{tabular}{|l|l|r|}
\hline \multicolumn{2}{|l|}{} & $\begin{array}{l}\text { Unstandardized } \\
\text { Predicted Value }\end{array}$ \\
\hline $\mathrm{N}$ & Mean & 40 \\
\hline Normal Parameters & , &, 4060000 \\
\cline { 2 - 3 } & Std. Deviation &, 10827897 \\
\hline Most Extreme Differences & Absolute &, 110 \\
\cline { 2 - 3 } & Positive &, 104 \\
\hline
\end{tabular}




\begin{tabular}{|l|r|}
\hline & Negative \\
\hline Test Statistic &,- 110 \\
\hline Asymp. Sig. (2-tailed) &, $200^{\mathrm{c}, \mathrm{d}}$ \\
\hline a. Test distribution is Normal. \\
\hline b. Calculated from data. \\
\hline c. Lilliefors Significance Correction. \\
\hline d. This is a lower bound of the true significance. \\
\hline
\end{tabular}

Salah satu cara menguji normalitas suatu variabel penelitian dengan menggunakan uji Kolmogorov-Smirnov, jika hasil uji menunjukkan nilai Asymp, Sig. lebih kecil dari 0,05 (Asymp, Sig. < 0,05) maka data dinyatakan tidak normal. Pada tabel terlihat bahwa nilai Asymp. Sig. (2-tailed) sebesar ,200. Dimana angka,200 > 0,05 maka data yang digunakan pada penelitian ini adalah terdistribusi secara normal.

Table 4.3

\begin{tabular}{|c|c|c|c|}
\hline \multicolumn{4}{|c|}{ coefficients $^{\mathrm{a}}$} \\
\hline \multirow{2}{*}{\multicolumn{2}{|c|}{ Model }} & \multicolumn{2}{|c|}{ Collinearity Statistics } \\
\hline & & Tolerance & VIF \\
\hline \multirow[t]{3}{*}{1} & (Constant) & & \\
\hline & ROA & ,892 & 1,121 \\
\hline & CR & ,892 & 1,121 \\
\hline
\end{tabular}

Untuk uji multikolinieritas mempunyai nilai $1,121<5$ baik Return On Asset maupun Current Ratio dengan nilai tolerance, $892>0,1$ hal ini menunjukkan bahwa data penelitian yang digunakan tidak mengalami kondisi multikolinieritas.

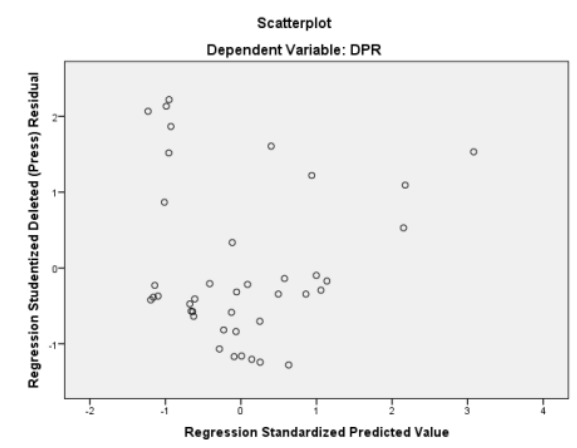

Gambar 4.1

ScatterPlot

Melihat dari gambar diagram ScatterPlot yang ada, maka dapat ditarik kesimpulan bahwa data penelitian ini tidak menunjukkan adanya gejala heteroskedastisitas, dengan melihat tersebarnya titik-titik pada gambar.

Tabel 4.4

Coefficients $^{\mathrm{a}}$

\begin{tabular}{|c|c|c|c|c|c|c|}
\hline \multirow{2}{*}{\multicolumn{2}{|c|}{ Model }} & \multicolumn{2}{|c|}{ Unstandardized Coefficients } & \multirow{2}{*}{$\begin{array}{l}\text { Standardized } \\
\text { Coefficients } \\
\text { Beta }\end{array}$} & \multirow[b]{2}{*}{$\mathrm{t}$} & \multirow[b]{2}{*}{ Sig. } \\
\hline & & B & Std. Error & & & \\
\hline \multirow{3}{*}{1} & (Constant) & 265 &, 114 & & 2,335 &, 025 \\
\hline & ROA & $-9,614$ & ,001 &,- 017 &,- 104 & ,917 \\
\hline & CR & ,001 &, 000 & 297 & 1,793 & 081 \\
\hline
\end{tabular}


Untuk uji regresi linier, digunakan uji regresi linier berganda, karena variabel independen pada penelitian ini lebih dari satu. Sesuai dengan tabel yang ada, maka dapat disimpulkan bahwa penelitian ini telah memenuhi persamaan regresi berganda dengan nilai:

\section{$\mathrm{Y}=\mathbf{0 , 2 6 5}-\mathbf{9 , 6 1 4 R O A}+\mathbf{0 , 0 0 1 C R}$}

Berdasarkan persamaan, nilai konstanta sebesar 0265 menunjukkan bahwa apabila nilai variabel independen dianggap konstan maka kebijakan devden pada perusahaan sub Sektor Aneka Industriyang terdaftar di Bursa Efek Indonesia sebesar 0,265. Nilai koefisien regresi linear berganda X3 sebesar -9,614 dengan arah hubungan negatif menunjukkan bahwa apabila Return On Assets mengalami kenaikkan 1\% maka akan diikuti oleh penurunan 1\% kebijakan deviden sebesar -9,614 dengan asumsi variabel independen lainnya dianggap konstan. Nilai koefisien regresi linear berganda X2 sebesar 0,001 dengan arah hubungan positif menunjukkan bahwa apabila Current Ratio mengalami kenaikkan $1 \%$ maka akan diikuti oleh peningkatan $1 \%$ kebijakan deviden sebesar 0.001 dengan asumsi variabel independen lainnya dianggap konstan.

Uji signifikan statistik digunakan untuk menunjukkan pengaruh variabel independen terhadap variabel dependen secara simultan.

Tabel 4.5

Anova

\begin{tabular}{|l|l|r|r|r|r|r|}
\hline \multicolumn{1}{|l|}{ Model } & Sum of Squares & Df & Mean Square & \multicolumn{1}{c|}{ F } & Sig. \\
\hline \multirow{3}{*}{1} & Regression &, 457 & 2 &, 229 & 1,877 &, $167^{\mathrm{b}}$ \\
\cline { 2 - 7 } & Residual & 4,507 & 37 &, 122 & & \\
\cline { 2 - 7 } & Total & 4,964 & 39 & & & \\
\hline
\end{tabular}

Berdasarkantabel nilai $f_{\text {hitung }}$ sebesar 1,877 dengan tingkat signifikan sebesar 0.167.

Sedangkan nilai $\mathrm{f}_{\text {tabel }}$ diketahui sebesar 3.25 . berdasarkan hasil tersebut dapat diketahui bahwa $\mathrm{f}_{\text {hitung }}<\mathrm{f}_{\text {tabel }}(1,877<3.25)$ artinya $\mathrm{H}_{0}$ diterima dan $\mathrm{H}_{a}$ ditolak. Jadi dapat disimpulkan bahwa variabel Return On Assets, Current Ratio tidak berpengaruh dan tidak signifikan terhadap kebijkaan deviden pada perusahaan industris konsumsi yang Terdaftar di Bursa Efek Indonesia.

Uji statistik secara parsial dilakukan untuk menunjukkan pengaruh masing-masing variabel independen terhadap variabel dependen.

Nilai $t_{\text {hitung }}$ untuk variabel Return On Assets adalah -0,104 dan $t_{\text {tabel }}$ dengan $\alpha=5 \%$ diketahui sebesar -2.024 dengan demikian - $t_{\text {hitung }}$ lebih besar dari $-t_{\text {tabel }}$ dan nilai signifikan Return On Assets sebesar $0.917>0.05$ artinya dari hasil tersebut didapat kesimpulan bahwa H0 diterima (Ha ditolak) menunjukkan bahwa Return On Assets tidak berpengaruh dan tidak signifikan terhadap kebijkan deviden pada perusahaan sub industrsi konsumsi yang terdaftar di Bursa Efek Indonesia.

Nilai $t_{\text {hitung }}$ untuk variabel Current Ratio adalah 1,793 dan $t_{\text {tabel }}$ dengan $\alpha=5 \%$ diketahui sebesar 2.024. dengan demikian $t_{\text {hitung }}$ lebih kecil dari $t_{\text {tabel }}$ dan nilai signifikan Current Ratio sebesar $0.081>0.05$ artinya dari hasil tersebut didapat kesimpulan bahwa H0 diterima (Ha ditolak) menunjukkan bahwa Current Ratio tidak berpengaruh dan tidak signifikan terhadap kebijkan deviden pada perusahaan sub industrsi konsumsi yang terdaftar di Bursa Efek Indonesia.

Nilai R-square dari koefisien determinasi digunakan untuk melihat bagaimana variasi nilai variabel terikat dipengaruhi oleh nilai variabel bebas. Nilai koefisien determinasi adalah antara 0 dan 1 . Apabila nilai R-square semakin mendekati satu maka semakin besar pengaruh variabel bebas terhadap variabel terikat.

Tabel 4.6

Model Summary ${ }^{\mathrm{b}}$

\begin{tabular}{|l|l|l|l|l|}
\hline Model & R & R Square & & \\
\hline
\end{tabular}




\begin{tabular}{|l|r|r|r|}
\hline & & $\begin{array}{c}\text { Adjusted R } \\
\text { Square }\end{array}$ & $\begin{array}{c}\text { Std. Error of the } \\
\text { Estimate }\end{array}$ \\
\hline 1 &, $303^{\mathrm{a}}$ &, 092 & \\
\hline
\end{tabular}

Berdasarkan tabel dapat dilihat bahwa nilai dari R square sebesar 0.092 yang berarti 9,2\% dan hal ini menyatakan bahwa variabel return on assets, current ratio sebesar 9,2\% untuk mempengaruhi variabel kebijakan deviden. Selanjutnya selisih 9,2\% $-100 \%=91,1 \%$. hal ini menujukkan 91,1\% tersebut adalah variabel lain yang tidak berkontribusi terhadap penelitian kebijkaan deviden.

\subsection{Pembahasan}

Hasil temuan dalam penelitian ini adalah mengenai hasil temuan penelitian ini terhadap kesesuaian teori, pendapat maupun penelitian terdahulu yang telah dikemukakan hasil penelitian sebelumnya serta pola perilaku yang harus dilakukan untuk mengatasi hal-hal tersebut. Berikut ini ada tiga bagian utama yang akan dibahas dalam analisis hasil temuan penelitian ini, yaitu sebagai berikut:

\section{Pengaruh Return On Assets Terhadap Kebijakan Deviden}

Berdasarkan penelitian yang diperoleh mengenai pengaruh Return On Assets terhadap Kebijkan Deviden pada hasil uji hipotesis secara parsial menunjukkan bahwa nilai $t_{\text {hitung }}$ untuk variabel Return On Assets adalah -0,104 dan $t_{\text {tabel }}$ dengan $\alpha=5 \%$ diketahui sebesar 2.024. dengan demikian $-t_{\text {hitung }}$ lebih besar dari $-t_{\text {tabel }}$ dan nilai signifikan Return On Assets sebesar $0.917>0.05$ artinya dari hasil tersebut didapat kesimpulan bahwa H0 diterima (Ha ditolak)

Berdasarkan hasil tersebut dapat disimpulkan Return On Assets tidak berpengaruh dan tidak signifikan terhadap kebijakan deviden hal ini menunjukkan bahwa dengan semakin meningkatnya Return On Assets maka kebijakan deviden akan semakin menurun dimana perusahaan telah memiliki banyak cadangan laba yang dapat digunakan baik untuk diinvestasikan kembali maupun dibagikan dalam bentuk deviden tanpa harus merubah proporsi deviden bagi pemegang saham yang sebgian besar juga merupakan pemegang saham pengendali dan tanpa tergantung pada besarnya Return On Assets yang diperoleh perusahaan.

Semakin besar Return On Asset menunjukkan kinerja perusahaan yang semakin baik karena tingkat kembalian investasi (return) yang semakin besar. (Hanafi \& Halim, 2017) perusahaan yang mempunyai aliran kas atau profitabilitas yang baik bisa membayar deviden atau meningkatkan deviden ". Hal yang sebaliknya akan terjadi jika jika aliran kas tidak baik. Alasan lain pembayaran dividen adalah untuk menghindari akuisisi oleh perusahaan lain. Perusahaan yang mempunyai kas yang berlebihan seringkali menjadi target dalam akuisisi. Untuk menghindari akuisisi, perusahaan tersebut bisa membayarkan dividen, dan sekaligus juga membuat senang pemegang saham.

Penelitian ini sejalan dengan penelitian terdahulu yang dilakukan oleh (Arseto \& Jufrizen, 2018) menyimpulkan bahwa Return On Assets tidak berpengaruh terhadap kebijakan deviden.

Sedangankan menurut (Wahyuni \& Hafiz, 2018) menyimpulkan bahwa Return On Assest berpengaruh terhadap kebijakan deviden.

\section{Pengaruh Current Ratio Terhadap Kebijakan Deviden}

Berdasarkan penelitian yang diperoleh mengenai pengaruh Current Ratio terhadap Kebijkan Deviden pada hasil uji hipotesis secara parsial menunjukkan bahwa nilai $t_{\text {hitung }}$ untuk variabel Current Ratio adalah 1,793 dan $t_{\text {tabel }}$ dengan $\alpha=5 \%$ diketahui sebesar 2.024. 
Dengan demikian $t_{\text {hitung }}$ lebih kecil dari $t_{\text {tabel }}$ dan nilai signifikan Current Ratio sebesar 0.081 $>0.05$ artinya dari hasil tersebut didapat kesimpulan bahwa H0 diterima (Ha ditolak)

Berdasarkan hasil tersebut dapat disimpulkan Current Ratio tidak berpengaruh dan tidak signifikan terhadap kebijakan deviden hal ini menunjukkan bahwa Current Ratio tidak mampu meningkatkan kebijakan deviden pada perusahaan Sektor Aneka Industri yang terdaftar di Buesa Efek Indonesia dimana disebabkan setiap perusahaan memiliki kemampuan masing-masing dalam memenuhi kewajiban atau hutang lancarnya. Untuk mengetahui kemampuan kewajiban lancarnya yang dimiliki perusahaan dapat dilihat dari aktiva lancarnya. Jika hutang lancar melebihi aktiva lancar yang dimiliki perusahaan, berarti perusahaan tidak mampu menanggung hutang jangka pendeknya yang dijamin oleh aktiva lancarnya. Tetapi semakin besar perusahaan untuk memenuhi kebutuhan jangka pendeknya dengan aktiva lancar, maka posisi kas akan semakin kuat sehingga kemampuan perusahaan untuk membayar dividen semakin besar.

Semakin tinggi current ratio ini berarti semakin besar kemampuan perusahaan untuk memenuhi kewajiban finansial jangka pendek. Aktiva lancar yang dimaksud termasuk kas, piutang, surat berharga dan persediaan. Dari aktiva tersebut, persediaan merupakan aktiva lancar yang kurang likuid dibanding yang lain

Hasil penelitian ini sejalan dengan penelitian yang dilakukan oleh (Wahyuni \& Hafiz, 2018) (Nurhayati, 2013) menyimpulkan bahwa Current Ratio tidak berpengaruh terhadap kebijakan deviden.

Sedangkan penelitian yang dilakukan oleh (Arseto \& Jufrizen, 2018) berpengaruh positif terhadap kebijakan deviden.

\section{Pengaruh Return On Assets, Current Ratio Terhadap Kebijakan Deviden}

Berdasarkan penelitian yang diperoleh mengenai pengaruh Return On Assets dan Current Ratio terhadap Kebijkan Deviden pada hasil uji hipotesis secara parsial menunjukkan bahwa nilai $\mathrm{f}_{\text {hitung }}$ sebesar 1,877 dengan tingkat signifikan sebesar 0.167. Sedangkan nilai $\mathrm{f}_{\text {tabel }}$ diketahui sebesar 3.25 berdasarkan hasil tersebut dapat diketahui bahwa $\mathrm{f}_{\text {hitung }}<\mathrm{f}_{\text {tabel }}$ $(1,877<3.25)$ artinya $\mathrm{H}_{0}$ diterima dan $\mathrm{H}_{a}$ ditolak

Berdasarkan hasil tersebut sehingga dapat disimpulkan bahwa Return On Assets Current Ratio tidak berpengaruh dan tidak signifikan terhadap kebijakan deviden pada perusahaan sub Sektor Aneka Industriyang terdasftar di Bursa Efek Indonesia.

Hal ini disebab kan aset lancar yang dimiliki perusahaan tidak dapat dikelola dengan baik sehingga produktivitas perusahaan kurang maksimal dengan kurang maksimal nya produktivitas perusahaan maka penjualan kurang maksimal dengan kurang maksimalnya penjualan maka laba kurang maksimal sehingga mengakibatkan menurunnya laba per saham dan juga diikuti menurunnya deviden perusahaan.

Dividend Payout Ratio merupakan rasio pembayaran dividen, ikut menentukan besarnya jumlah laba yang ditahan perusahaan harus dievaluasi dalam kerangka tujuan pemaksimalan kekayaan para pemegang saham. Jika marginal return para investor tidak berada pada kondisi indifferent antara dividen sekarang dengan capital gains.

Semakin besar Return On Asset menunjukkan kinerja perusahaan yang semakin baik karena tingkat kembalian investasi (return) yang semakin besar. (Hanafi \& Halim, 2017) perusahaan yang mempunyai aliran kas atau profitabilitas yang baik bisa membayar deviden atau meningkatkan deviden ". Hal yang sebaliknya akan terjadi jika jika aliran kas tidak baik. Alasan lain pembayaran dividen adalah untuk menghindari akuisisi oleh perusahaan lain. Perusahaan yang mempunyai kas yang berlebihan seringkali menjadi target dalam akuisisi. Untuk menghindari akuisisi, perusahaan tersebut bisa membayarkan dividen, dan sekaligus juga membuat senang pemegang saham.

Setiap perusahaan memiliki kemampuan masing-masing dalam memenuhi kewajiban atau hutang lancarnya. Untuk mengetahui kemampuan kewajiban lancarnya yang dimiliki perusahaan dapat dilihat dari aktiva lancarnya. Jika hutang lancar melebihi aktiva lancar yang 
dimiliki perusahaan, berarti perusahaan tidak mampu menanggung hutang jangka pendeknya yang dijamin oleh aktiva lancarnya. Tetapi semakin besar perusahaan untuk memenuhi kebutuhan jangka pendeknya dengan aktiva lancar, maka posisi kas akan semakin kuat sehingga kemampuan perusahaan untuk membayar dividen semakin besar

\section{Kesimpulan dan Saran 5.1 Kesimpulan}

Berdasarkan data yang diperoleh maupunn analisis data yang telah dilakukan serta pembahasan yang telah dilakukan pada bab sebelumnya, maka dapat ditarik kesimpulan mengenai Pengaruh Return On Assets dan Current Ratio Terhadap Kebijakan Deviden pada perusahaan sub industrsi yang terdaftar di Bursa Efek Indonesia: secara parsial Return On Assets tidak berpengaruh dan tidak signifikan terhadap kebijakan deviden pada perusahaan sub Sektor Aneka Industriyang terdaftar di Bursa Efek Indonesia, secara parsial Current Ratio tidak berpengaruh dan tidak signifikan terhadap kebijakan deviden pada perusahaan sub Sektor Aneka Industriyang terdaftar di Bursa Efek Indonesia, dan secara simultan Return On Assets, Current Ratio tidak berpengaruh dan tidak signifikan terhadap kebijakan deviden pada perusahaan sub Sektor Aneka Industriyang terdaftar di Bursa Efek Indonesia.

\subsection{Saraan}

Berdasarkan kesimpulan diatas maka saran-saran yang dapat diberikan pada penelitian ini antara lain: pihak perusahaan agar dapat mengelola seluruh aset lancarnya serta keseluruhan asetnya sehingga laba yang diperoleh semakin maksimal dengan mengusahakan tidak banyak idle assets, meningkatkan laba per lembar sahahamnya dapat dilakukan dengan memanfaatkan aktivanya dan modal yang ditanamkan untuk menghasilkan laba bersih. Untuk meningkatkan perolehan laba bersih dengan cara meminimalkan beban pokok produksi dan beban-beban lainnya, sehingga tujuan efisiensi tercapai dan laba bersih akan meningkat.

\section{Referensi}

Aresto, D. D., \& Jufrizen, J. (2018). Pengaruh Return On Assets dan Current Ratio Terhadap Deviden Payout Ratio Dengan Firm Size Sebagai Variabel Moderating. Manggeio: Jurnal Ilmiah Magister Manajemen, 1(1), 15-30.

Brigham, E. F., \& Houtson, J. F. (2015). Dasar-Dasar Manajemen Keuangan. Jakarta: Salemba Empat.

Gumanti, T. A. (2015). Kebijakan Dividen Teori, Empiris, dan Implikasi. Jakarta: UPP STIM YKPN.

Hanafi, M., \& Halim, A. (2017). Analisis Laporan Keuangan. Yogyakarta: Unit Penerbit dan Percetakan Sekolah Tinggi Ilmu Manajemen.

Hery. (2016). Analisis Laporan Keuangan. Jakarta: Grasindo Monoratam.

Hikmah, K. (2011). Analisis Faktor-Faktor yang Mempengaruhi Kebijakan Dividen: Pendekatan Teori Stakeholder. KRISNA, 4(2), 91-105.

Home, V., \& Wachowicz. (2015). Prinsip - Prinsip Manejemen Keuangan. Jakarta: Salemba Empat.

Jufrizen, J., \& Sari, M. (2019). Pengaruh Current Ratio, Debt to Equituy Ratio dan Firm Size Terhadap Return On Equity. Aksioma: Jurnal Riset Akuntansi, 18(1), 156-181. Retrieved from http://aksioma.unram.ac.id/index.php/aksioma/article/view/58

Jufrizen, J., Sari, M., Radiman, R., Muslih, M., \& Putri, A. M. (2019). Pengaruh Debt Ratio, Long Term Debt To Equity Ratio dan Kepemilikan Instutisional Terhadap Return On Assets Pada Perusahaan Sub Sektor Makanan dan Minuman Yang Terdaftar Di Bursa Efek Indonesia. Jurnal Manajemen Motivasi, 15(1), 7-18. Retrieved from http://openjurnal.unmuhpnk.ac.id/index.php/jm_motivasi/article/view/1376

Juliandi, A., Irfan, I., \& Manurung, S. (2015). Metodelogi Penelitian Bisnis Konsep dan 
Aplikasi. Medan: UMSU PRESS.

Jumingan. (2017). Analisis Laporan Keuangan. Jakarta: PT. Bumi Aksara.

Kasmir. (2017). Analisis Laporan Keuangan. Jakarta: PT. Raja Grafindo Persada.

Martono., \& Harjito, A. (2010). Manajemen Keuangan (Edisi 3). Yogyakarta :Ekonisia.

Munawir, S. (2015). Analisis Laporan Keuangan. Yogyakarta: Andi.

Muslih, M. (2019). Pengaruh Perputaran Kas dan Likuiditas (Current Ratio) Terhadap Profitabilitas (Return On Assets). Krisna: Kumpulan Riset Akuntansi, 11(1), 47-59. Retrieved from https://www.ejournal.warmadewa.ac.id/index.php/krisna/article/view/1126

Nurhayati, M. (2013). Profitabilitas, Likuiditas, dan Ukuran Perusahaan Pengaruhnya Terhadap Kebijakan Dividen dan Nilai Perusahaan Sektor Non Jasa. Jurnal Keuangan Dan Bisnis, 5(2), 1-10.

Prihanthini, N. M. E. D., \& Sari, M. M .R. (2013). Prediksi Kebangkrutan dengan Model Grover, Altman Z-Score, Springate dan Zmijewski pada Perusahaan Food And Beverage di Bursa Efek Indonesia, E-Jurnal Akuntansi Universitas Udayana, 5(2), 417-435

Riyanto, B. (2017). Dasar-Dasar Pembelanjaan Perusahaan. Yogyakarta: BPEEYogyakarta.

Sartono, A. (2015). Manajemen Keuangan Teori dan Aplikasi. Yogyakarta: BPEEYogyakarta.

Siswantini, W. (2014). Pengaruh Analisis Rasio Keuangan Terhadap Kebijakan Deviden (Studi Empiris pada Perusahaan Real Estate dan Property yang Terdaftar di Bursa Efek Indonesia). Jurnal Organisasi dan Manajemen, 10(2), 136-147.

Stice, J., Earl. K. S., \& Fred, S. K. (2015). Akuntansi Keuangan Menengah 1 dan 2(Intermediate Accoutitng land 2), Jakarta : Penerbit Salemba Empat.

Sudana, I. M. (2015). Manajemen Keuangan Perusahaan. Jakarta: Salemba Empat. Sugiyono. (2018). Metode Penelitian Kuantitatif, Kualitatif dan R\&D. Bandung: Alfabeta.

Utami, G. K., \& Robin. (2015). Analisis Faktor-Faktor yang MempengaruhiRasio Pembayaran Dividen pada Perusahaan yang Terdaftar di Bursa Efek Indonesia, Jurnal Manajemen, 15(1),.41-58.

Wahyuni, S. F. (2017). Peran Kepemilikan Institusional Dalam Memoderasi Pengaruh Current Ratio, Debt To Equity Ratio, Total Asset Turnover Dan Inventory Turnover Terhadap Return On Equity Di Bursa Efek Indonesia. Jurnal Riset Finansial Bisnis, 1(2), 147158. Retrieved from https://ejurnal.id/index.php/jrfb/article/view/107

Wahyuni, S. F., \& Hafiz, M. H. (2018). Pengaruh CR, DER dan ROA Terhadap DPR Pada Perusahaan Manufaktur di BEI. Jesya: Jurnal Ekonomi \& Ekonomi Syariah, 1(2), 2542.

Wati, T. K., Stiyanto., \& Khaerunisa, E. (2018). Pengaruh Kebijakan Dividen Terhadap Nilai Perusahaan Dengan Kebijakan Hutang Sebagai Variabel Intervening Pada Perusahaan Sub Sektor Industri Barang Konsumsi Periode 2011-2016. Jurnal Manajemen Dan Bisnis, 11(1), 49-74.

www.idx.co.id.

Zais, G. M. (2017). Faktor-Faktor Yang Mempengaruhi Kebijakan Dividen Pada Perusahaan Industri Barang Konsumsi Di Bursa Efek Indonesia. Jurnal Kompetitif, 6(1), 10-28. 